\title{
EVENT MARKET SEGMENTATION: A REVIEW UPDATE AND RESEARCH AGENDA
}

\author{
AARON TKACZYNSKI* AND SHARYN RUNDLE-THIELE $\dagger$ \\ *Business, Economics \& Law, School of Business, University of Queensland, Queensland, Australia \\ $\nmid$ †usiness and Government, Social Marketing@Griffith, Griffith Business School, \\ Griffith University, Nathan, Australia
}

\begin{abstract}
Segmenting target audiences can deliver increases in audiences attending events. An examination of segmentation research progress in the field is needed to assess the extent that researchers are capitalizing on available opportunities. Following the Tkaczynski and Rundle-Thiele framework, this article reviews 90 segmentation articles published from 2010 onwards to examine attendee profiling practices and to assess research practice change over time. Nine research issues have been proposed, which are subsequently discussed. Findings indicate an increase in geographic reach (e.g., Africa and Europe) and a continued dominant focus on on-site self-administered surveys as the data collection method. Both sample sizes and application of multivariate data analysis techniques have increased, and studies are largely employing the same segmentation bases and variables across the two research reviews. Recommendations for future research such as a need for larger sample sizes to warrant segmentation and a greater focus on external validation of segments are outlined.
\end{abstract}

Key words: Events; Literature review; Market segmentation

Background

In their recent review of event research, Getz and Page (2016) argued that creating and managing events requires a marketing orientation and commitment to customer service. Echoing earlier research (e.g., Allen, O'Toole, Harris, \& McDonnell, 2008; Getz, 2007, 2008), the authors concluded that event organizers [e.g., destination marketing organizations (DMOs), local councils, and/or private companies] employing a demand perspective to event management would benefit from profiling event attendees given the potential that targeted approaches offer to innovate and grow events, at potentially a much lower cost and risk (Getz \& Page, 2016).

By employing market segmentation to profile event attendees based on variables such as

Address correspondence to Aaron Tkaczynski, Senior Lecturer, Business, Economics \& Law, School of Business, University of Queensland, Cnr Blair Drive \& Campbell Street, St Lucia QLD 4072, Australia. Tel: +61 733467093 ; Fax: +61 73346 8716; E-mail: a.tkaczynski@uq.edu.au 
expenditure, age, trip purpose, and usual place of residence, event organizers can attract and satisfy attendees that might visit the destination location where the event was held (Getz, 2008; Tkaczynski \& Rundle-Thiele, 2011). Additionally, segmentation of event attendees enables event organizers to estimate and evaluate the spending of event attendees, permitting enhanced understanding of where economic benefits are derived from. By understanding the different groups attending events, event organizers can limit seasonality of demand effects, further assisting development (Getz \& Page, 2016). By appealing to multiple target segments, improved leveraging for events can be realized and in turn destinations can be economically developed (Getz, 2007).

Segmentation studies of event attendees are frequent (Getz \& Page, 2016). Tkaczynski and RundleThiele (2011) reviewed 120 event segmentation articles that were published from 1992 to 2010 with the aim of developing a reference guide for event segmentation research. Major findings were that event researchers used a combination of demographic, geographic, psychographic, and/or behavioral bases (Kotler, 1980) to profile attendees and they employed various data collection methods and analysis techniques across numerous event contexts.

Although Tkaczynski and Rundle-Thiele's (2011) review provided a valuable overview of a diverse range of approaches that had been used to derive event attendee segments at the time, advancements in analytical approaches and data collection techniques have occurred since. For example, big data now offers the potential to combine different data sources, delivering a rich source of information for segmentation researchers to draw from. Moreover, recent advancements such as online social media (e.g., Facebook, Snapchat) and online marketplace and hospitality services (e.g., Airbnb, Flipkey) may have potentially influenced the purchase decisions and the travel behavior of event attendees. Additionally, further progression in the unique types of events such as culinary festivals (e.g., Getz, Andersson, Vujicic, \& Robinson, 2015) and wedding expositions (e.g., Daniels, Lee, \& Cohen, 2012; S. Kruger, Saayman, \& Ellis, 2014) may impact research design and approaches employed.

Event academics and practitioners have benefited greatly from development in the research field, particularly in the usage of technology (S. Lee, Boshnakova, \& Goldblatt, 2017; Preston, 2012). A variety of software packages available such as SurveyMonkey and Qualtrics have enabled researchers to collect data outside of the confines of a physical event setting. Furthermore, data sources such as search queries, online reviews and transaction data (Liu, Teichert, Rossi, Li, \& Hu, 2017; Pan \& Yang, 2017) have proliferated, enabling researchers access to larger samples and alternate data forms. Additionally, although traditional segmentation approaches may have employed descriptive statistics in the early to mid-1990s (Tkaczynski \& Rundle-Thiele, 2011), continual advancements in statistical packages such as Predictive Analytics Software (PASW) (a Statistical Packages for the Social Sciences update) have facilitated multivariate segmentation analysis techniques. Consequently, greater access to larger sample sizes and data analysis advancements facilitates the validity of multivariate analysis techniques such as factor analysis and cluster analysis (Dolnicar, Grün, \& Leisch, 2014), which can be employed in an event context. Application of more sophisticated multivariate data analysis alternatives has led to revisions in sample size recommendations and more (see Dolnicar Grün, \& Leisch, 2016, for current best practice guidelines).

To provide informed insight into recent advancements in event segmentation, this article seeks to conduct a comprehensive literature review. Specifically, this article profiles event segmentation studies that have been published following Tkaczynski and Rundle-Thiele (2011) to examine progress in the field. In addition to comparing and contrasting the findings between Tkaczynski and RundleThiele's (2011) study, this research aims to address the following issues:

- In which journals are event attendee segmentation articles published?

- Where are event attendee segmentation carried out?

- Which types of events are researched by event attendee segmentation researchers?

- What data collection method/s have been used to collect information from attendees?

- Which of the four segmentation bases developed by Kotler (1980) are used by researchers to profile attendees? 
- What variables were utilized by researchers to classify attendees?

- What data analysis methods were applied to segment attendees?

- Have sample sizes increased over time?

- Do sample sizes vary according to the data analysis techniques employed?

\section{Method}

A total of 90 academic event segmentation articles published from between 2010 and 2017 in 17 selected ranked event-focused journals form the basis of this study. Procedures reported in Tkaczynski and Rundle-Thiele (2011) were followed to establish which articles from each of the surveyed journals qualified for inclusion. First, at least one of Kotler's (1980) segmentation bases needed to be used to differentiate event attendees. Therefore, studies were considered that used segmentation bases and/or variables without the word "segmentation." Second, in a similar format to Tkaczynski and Rundle-Thiele's (2011) review, data reported in the articles (year of publication, sample size, data collection method, and analysis) were entered into PASW permitting additional analysis (e.g., descriptive analysis, chi-square analysis) to form the data set to assess segmentation practice. Tables 1-3 present the findings. In Table 1, articles are assembled in alphabetical order to provider clearer understanding to the reader. The event's name (e.g., 2014 Masquerade Festival) has been provided for further clarification and reference for the reader.

To understand how Table 1 has been summarized and presented, the following explanatory notes based on Tkaczynski and Rundle-Thiele (2011) are presented. If the event's name is not provided (e.g., confidentiality reasons), this event was simply listed as unnamed. If secondary data were utilized, a superscript "a" was placed after the sample size.

The column labeled Method deals with the different data collection techniques. These were coded as: self-administered mail survey (A), self-administer on-site survey (this included diaries and recollection methods) (B), personal interview (e.g., in-depth/ semistructured) (C), self-administered online survey (D), interviewer administered on-site survey $($ E), telephone interview $(F)$, and observation $(G)$. If a superscript "b" was listed after the method (letter) it indicated that the researcher/s employed past literature (e.g., festival motivation) as the basis for the event attendee segmentation research instrument. The Data Analysis column lists 12 different techniques that have been employed. These are coded as: descriptive statistics (I), chi-square test(s) (II), $t$ test(s) (III), factor analysis (IV), analysis of variance (V), cluster analysis (VI), regression (VII), correlation analysis (VIII), discriminant analysis (IX), qualitative analysis techniques (X), post hoc analysis (XI), and other analysis (XII).

Event Management is the dominant avenue for published event attendee segmentation research in both the current ( $24.4 \%$ of studies) and the initial (46.7\% of studies) reviews. Despite not being part of the initial review, the International Journal of Event and Festival Management has published several event segmentation studies $(12.2 \%$ total of the most recent review) since its inception in 2010. The Journal of Convention \& Exhibition Tourism [14.4\% (current) up from 2.5\% (initial)] and the Journal of Travel \& Tourism Marketing [10.0\% (current) up from $2.0 \%$ (initial)] were popular outlets for attendee segmentation research. The remaining 14 journals in the current review contributed to approximately two fifths $(39.0 \%)$ of segmentation studies summarized.

The highest number of segmentation studies (see Table 2) were conducted in the US [26.7\% (current) and $45.5 \%$ (initial)]. Event attendee segmentation research in South Africa (17.8\%) has increased dramatically since 2010 largely due to prolific research conducted by M. Kruger and associates (e.g., M. Kruger, Saayman, \& Ellis, 2011, 2012) across a variety of contexts (e.g.,, sports and culture). Conversely, Australia, while again the third most popular context for event segmentation research, reported slightly fewer studies $[11.1 \%$ (current review) compared to $13.3 \%$ (initial review)]. In total, 28 countries provided the research context, which is a slight increase from the 24 reported in Tkaczynski and Rundle-Thiele's (2011) review. Three studies (Getz \& McConnell, 2014; Horng, Su, \& So, 2013; Mair, 2010) compared attendees across two countries, a slightly higher increase (2 studies) from the initial review. For both reviews, the event locations (countries) were categorized into six continents (see Table 2). Chi-square analysis identified significant differences based on overall 
(3)

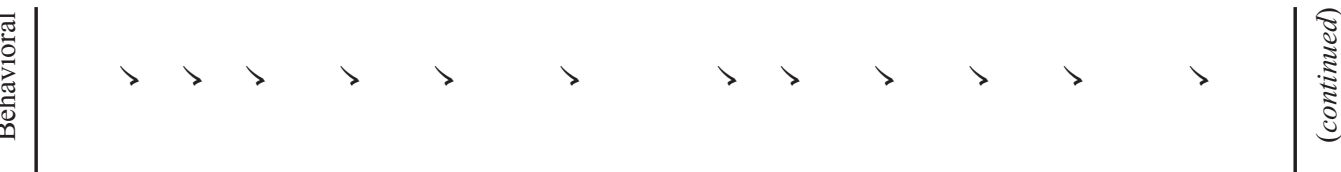

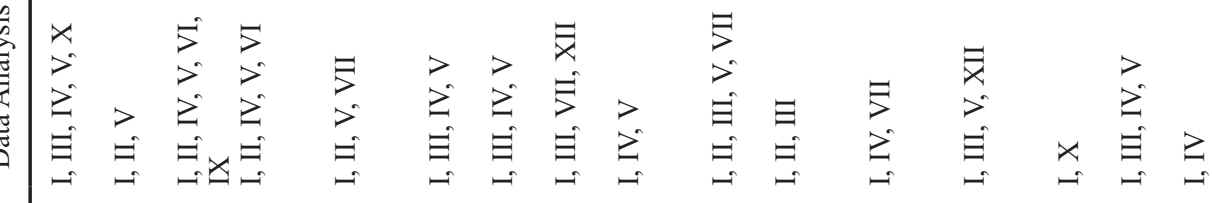

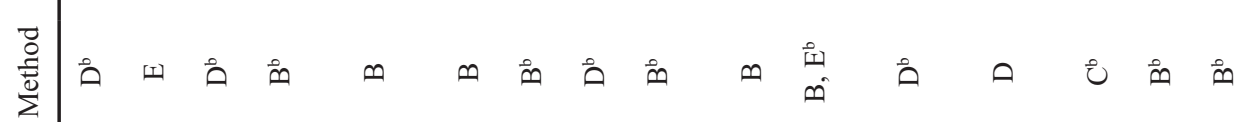

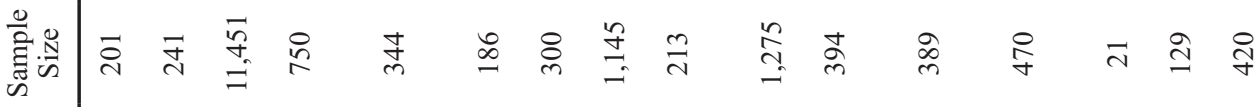

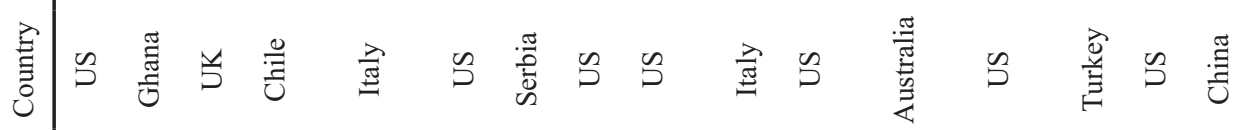

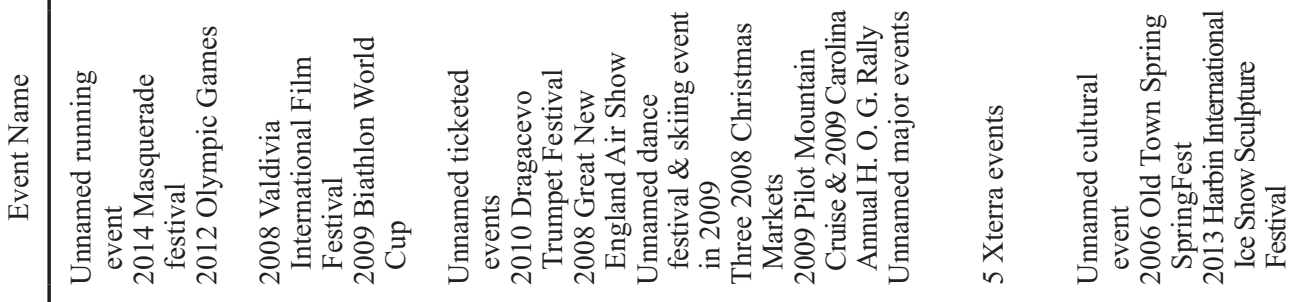

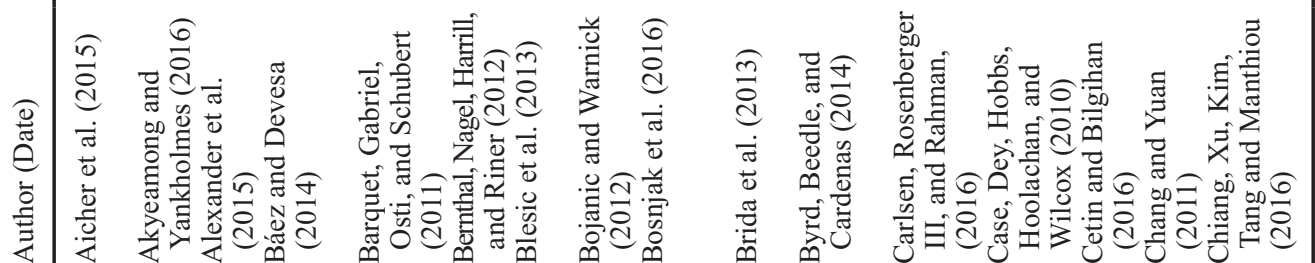




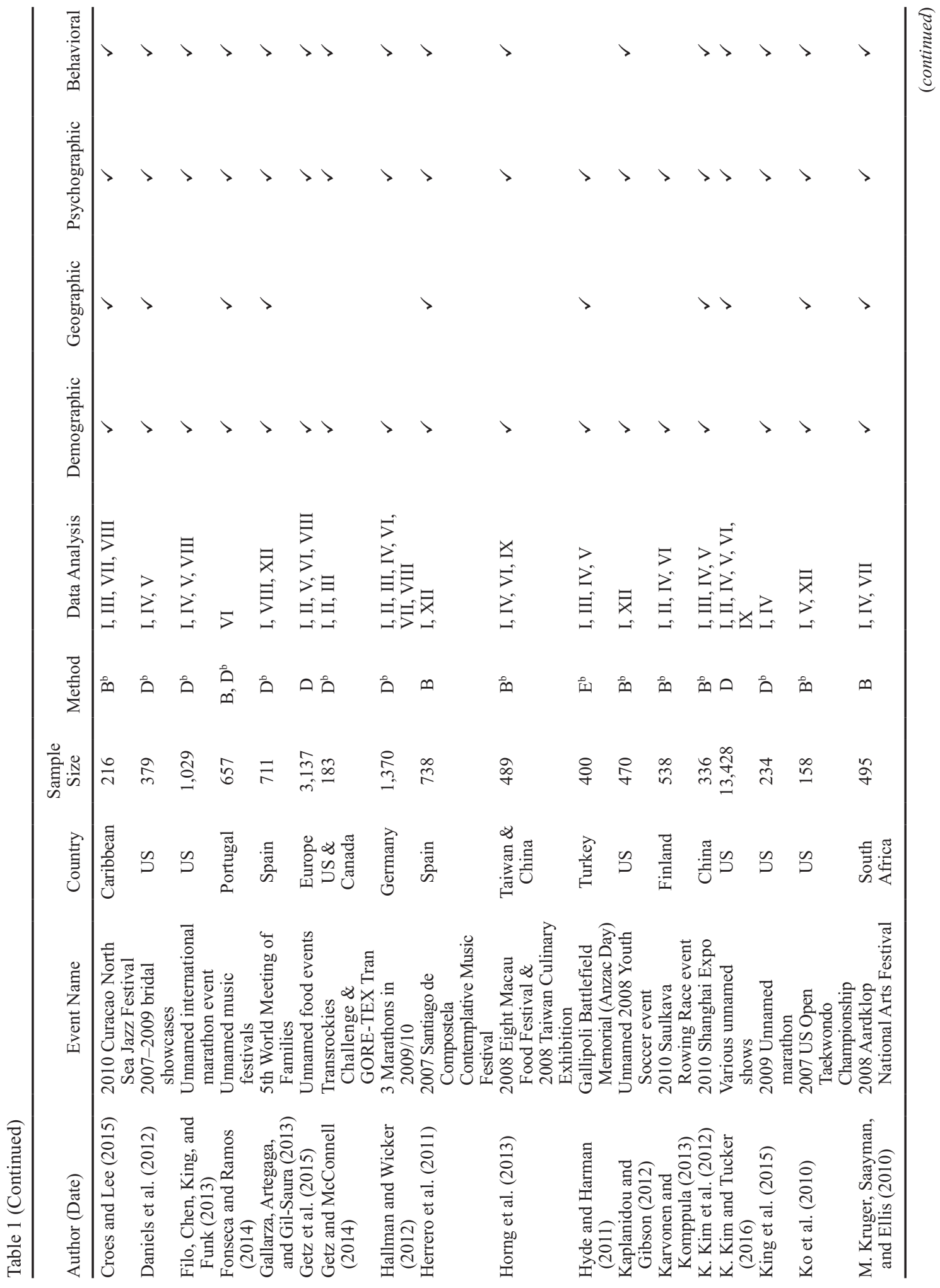




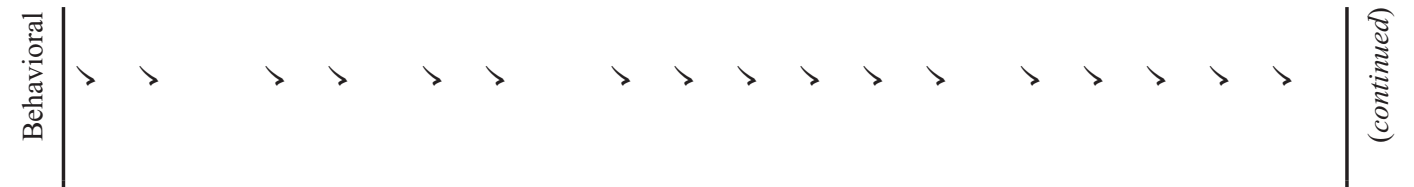

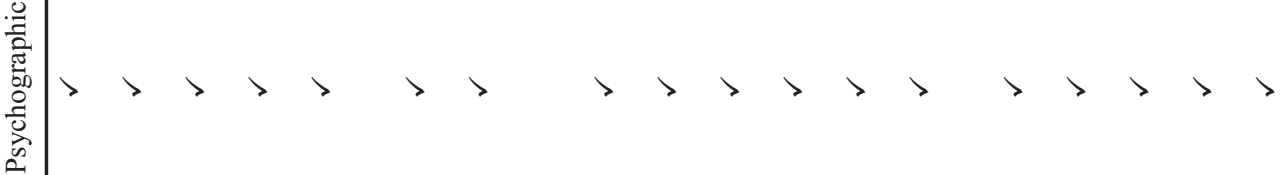
글 $\stackrel{8}{0}$ $\stackrel{\frac{\pi}{2}}{\frac{2}{2}}$ :

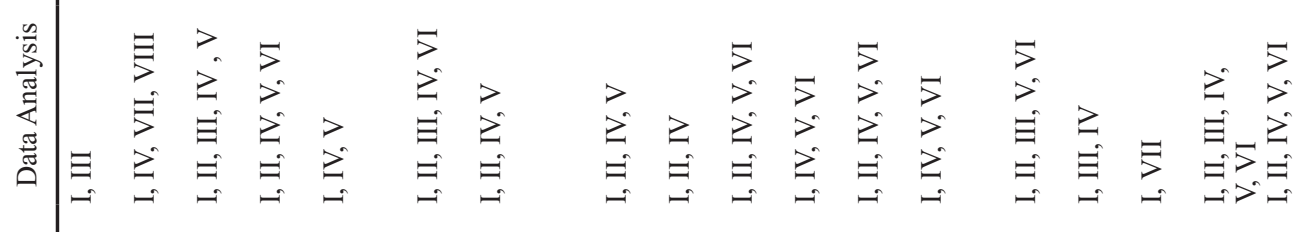

埅

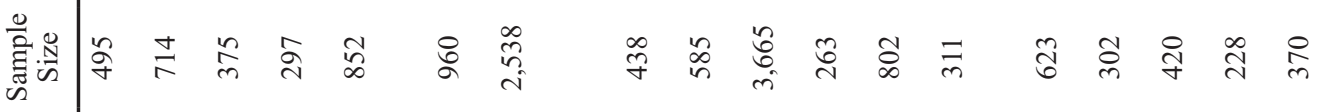

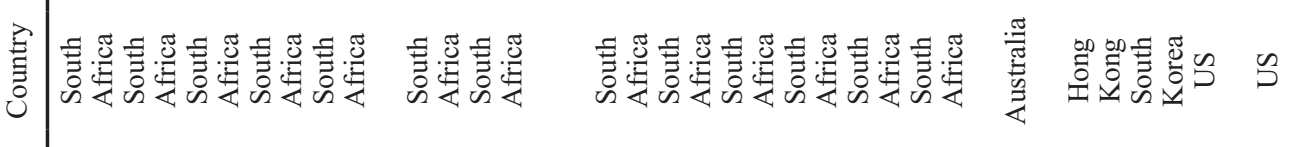

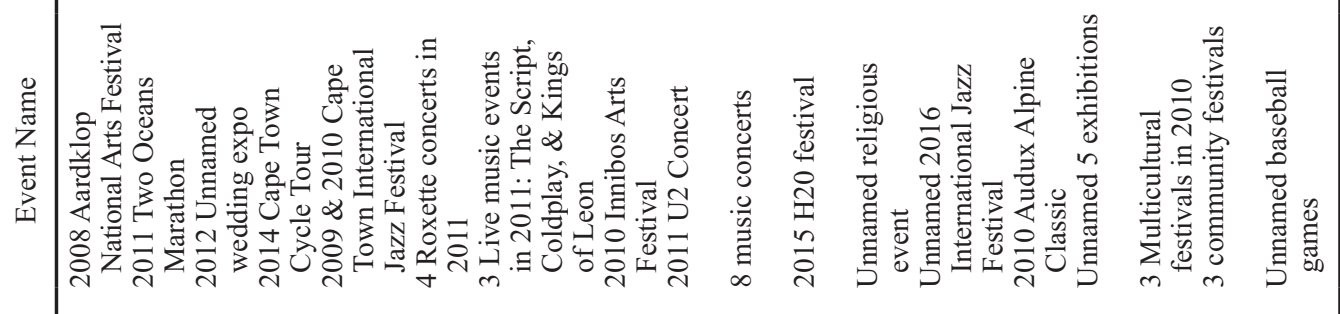




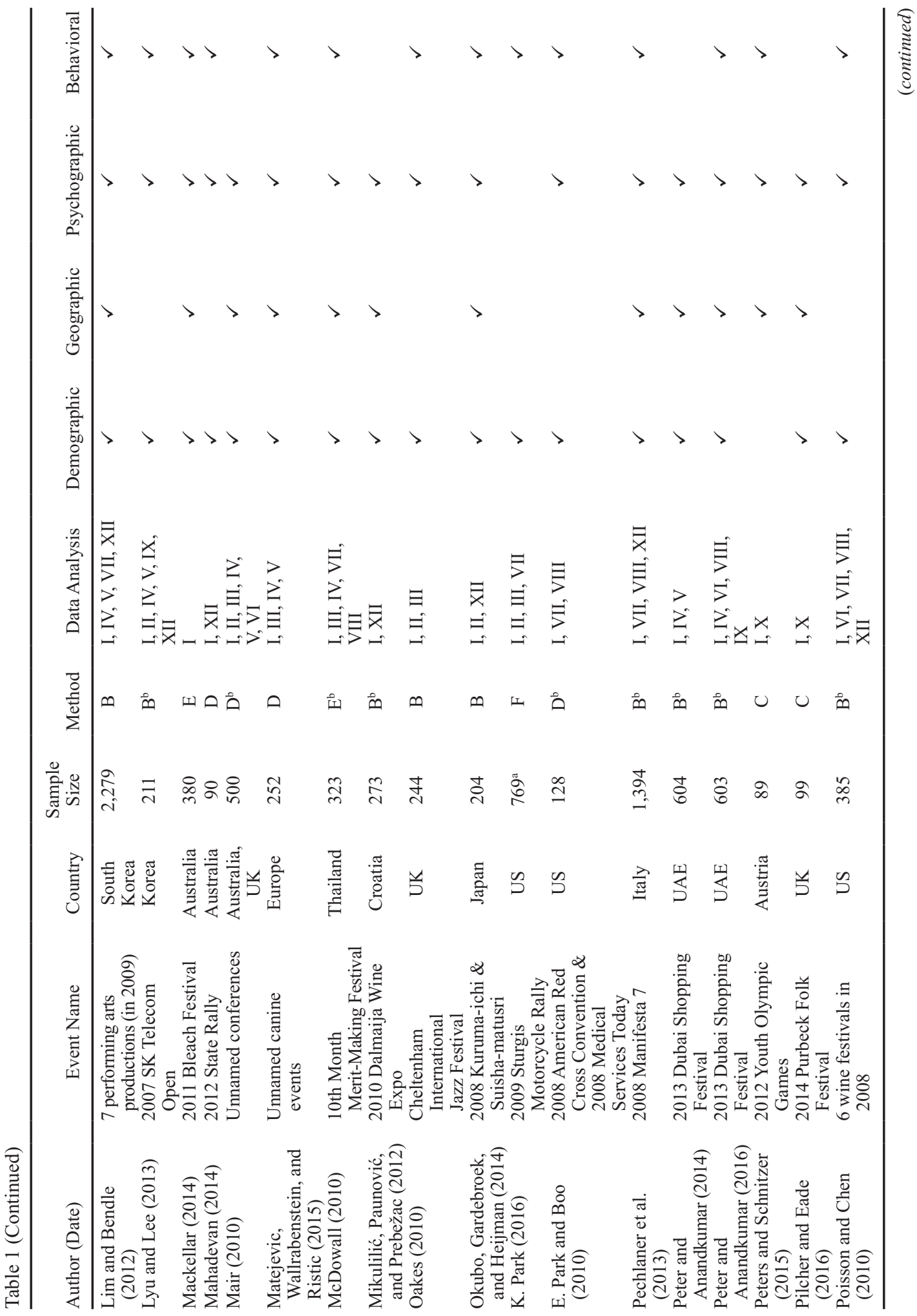




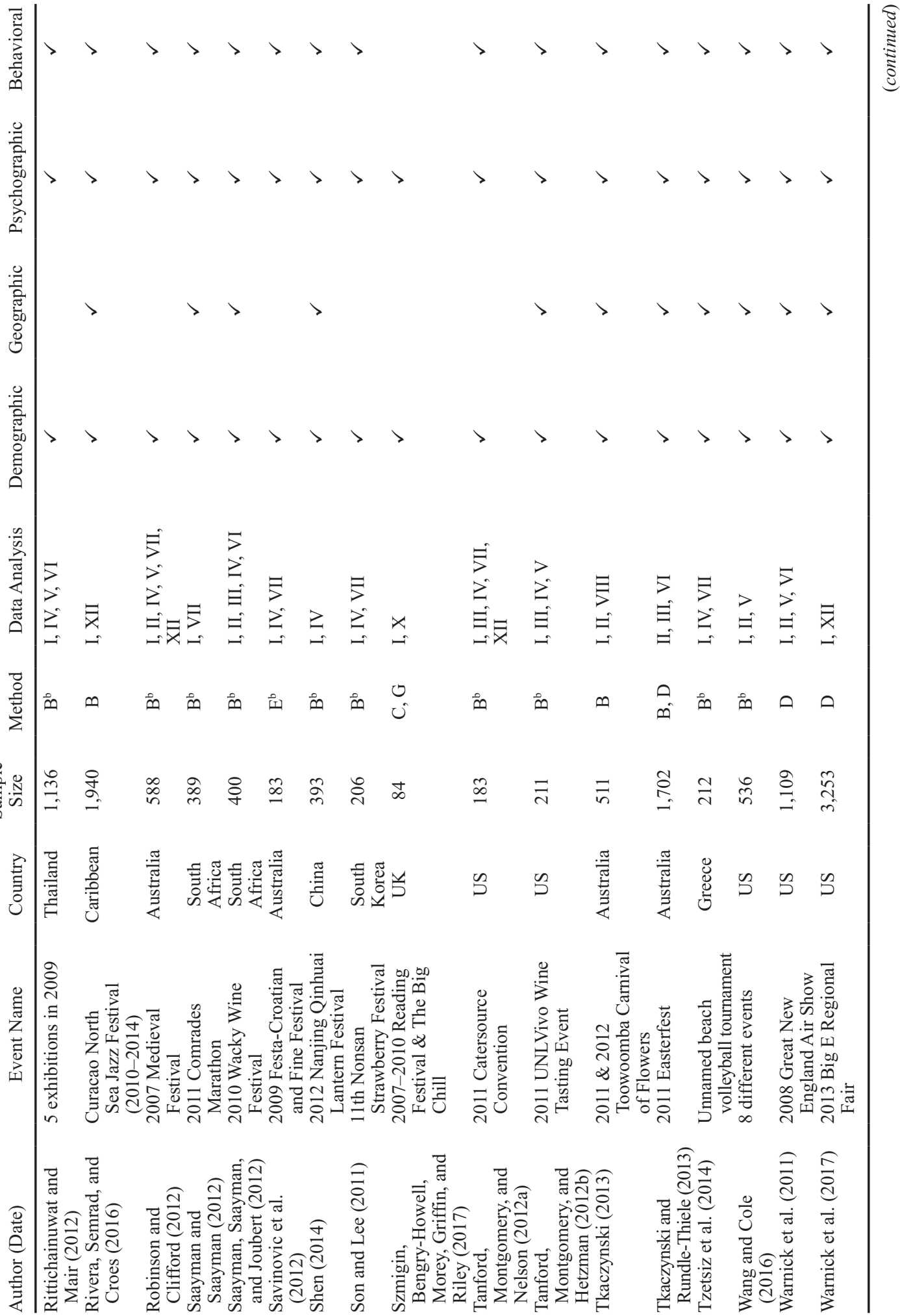




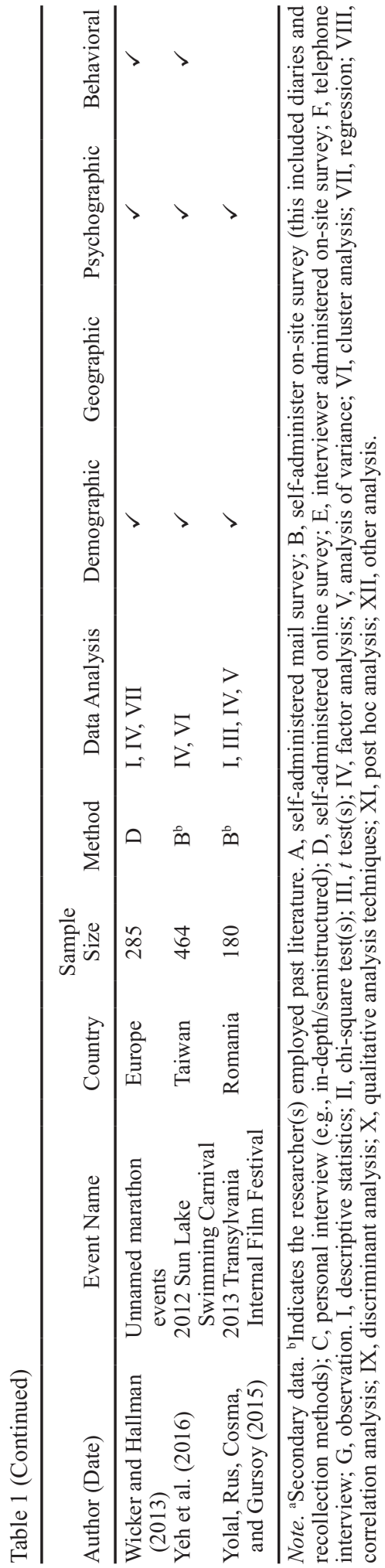

location $(p=0.00)$. No changes in the amount of studies reported across three continents namely, Asia $(p=0.960)$, Australasia $(p=0.073)$, and South America $(p=0.737)$ were observed.

In employing Getz and Page's (2016) event type categorization, it was noted (see Table 2) that in both reviews, cultural festivals (e.g., multicultural, music) dominated segmentation research. Sports events (e.g., marathons, Olympic Games) represented approximately a quarter of event segmentation studies in both reviews. Conversely, business events (e.g., conferences, exhibitions) were conducted in a minority of studies. In both reviews there were a few studies (e.g., Bosnjak, Brown, Lin, Yu, \& Sirgy, 2016; Nicholson \& Pearce, 2000) that were conducted at multiple event types (e.g., sport and cultural). Chi-square analysis identified no significant differences among event types (e.g., $p=0.092$ for culture, $p=0.419$ for sport) based on the two reviews.

On-site self-administered surveys remained the most frequently applied method [63.3\% (current) up from $45.8 \%$ (initial)], with an increase in use observed when compared to the previous review $(p=0.017)$ (see Table 2). Not surprisingly, online (e.g., web surveys), which were largely not available until the last decade, have increased dramatically $(27.8 \%$ up from $1.1 \%, p=0.000)$. The increased use in online surveys is expected given technology advances that are supportive of online data collection (e.g., Pan \& Yang, 2017). Both mail (1.1\% down from $25.8 \%$ of studies, $p=0.000)$ and interviewer-administered (6.7\% down from $31.7 \%$ of studies, $p=0.000$ ) surveys have decreased in use. A combined approach (5.6\%) was rarely reported in the current review, indicating a change in favored survey data collection methods.

In comparing reviews, it was concluded that the most popular segmentation approach employed was all four of Kotler's (1980) bases [46.7\% (current), $52.2 \%$ (initial) $p=0.425$ ] (see Table 2). Three bases [42.5\% (current), $41.1 \%$ (initial)] were also prevalent $(p=0.840)$. Two bases $[6.7 \%$ (current) and $8.3 \%$ (initial)] were infrequently employed $(p=0.652)$ and one base was not used in any of the 90 segmentation studies, whereas a small number $(2.5 \%)$ considered only one base (psychographics or behavioral) in the initial review. 
Table 2

Chi-Square Analysis (One Sample)

\begin{tabular}{|c|c|c|}
\hline & Initial & Current \\
\hline \multicolumn{3}{|l|}{ Location** } \\
\hline North America* & $47.5 \%$ & $28.9 \%$ \\
\hline Asia & $19.2 \%$ & $18.9 \%$ \\
\hline Australasia & $17.5 \%$ & $8.9 \%$ \\
\hline Europe* & $10.0 \%$ & $22.2 \%$ \\
\hline Africa* & $4.2 \%$ & $18.9 \%$ \\
\hline South America & $1.7 \%$ & $1.1 \%$ \\
\hline \multicolumn{3}{|l|}{ Event type } \\
\hline Cultural & $70.8 \%$ & $61.1 \%$ \\
\hline Sport & $26.7 \%$ & $28.9 \%$ \\
\hline Business & $5.8 \%$ & $12.2 \%$ \\
\hline Unnamed & $0.8 \%$ & $2.2 \%$ \\
\hline Multiple (e.g., cultural and sport) & $5.8 \%$ & $4.4 \%$ \\
\hline \multicolumn{3}{|l|}{ Data collection method } \\
\hline Mail survey** & $25.8 \%$ & $1.1 \%$ \\
\hline Self-administered on-site survey* & $45.8 \%$ & $63.3 \%$ \\
\hline Personal interview & $10.8 \%$ & $4.4 \%$ \\
\hline Online survey** & $2.5 \%$ & $27.8 \%$ \\
\hline $\begin{array}{l}\text { Interviewer-administered on-site } \\
\text { survey** }\end{array}$ & $31.7 \%$ & $6.7 \%$ \\
\hline Telephone interview & $4.2 \%$ & $1.1 \%$ \\
\hline Observation & $2.5 \%$ & $1.1 \%$ \\
\hline \multicolumn{3}{|l|}{ Segmentation bases } \\
\hline All four bases & $46.7 \%$ & $52.2 \%$ \\
\hline Three bases & $42.5 \%$ & $41.1 \%$ \\
\hline Two bases & $8.3 \%$ & $6.7 \%$ \\
\hline One base & $2.5 \%$ & $0.0 \%$ \\
\hline \multicolumn{3}{|l|}{ Segmentation variables } \\
\hline \multicolumn{3}{|l|}{ Demographic } \\
\hline Gender** & $71.7 \%$ & $91.1 \%$ \\
\hline Age & $83.3 \%$ & $92.2 \%$ \\
\hline Education & $50.8 \%$ & $62.2 \%$ \\
\hline Income & $50.8 \%$ & $57.8 \%$ \\
\hline Marital status & $22.5 \%$ & $31.1 \%$ \\
\hline Employment/occupation* & $27.5 \%$ & $42.2 \%$ \\
\hline Travel party composition & $32.5 \%$ & $21.1 \%$ \\
\hline Group size & $26.7 \%$ & $30.0 \%$ \\
\hline Ethnicity & $10.8 \%$ & $12.2 \%$ \\
\hline \multicolumn{3}{|l|}{ Geographic } \\
\hline Origin & $57.5 \%$ & $64.4 \%$ \\
\hline \multicolumn{3}{|l|}{ Psychographic } \\
\hline Motivations & $41.7 \%$ & $53.3 \%$ \\
\hline Trip purpose & $35.0 \%$ & $25.6 \%$ \\
\hline Perceptions & $23.3 \%$ & $31.1 \%$ \\
\hline Involvement & $15.8 \%$ & $13.3 \%$ \\
\hline Satisfaction & $16.7 \%$ & $27.8 \%$ \\
\hline \multicolumn{3}{|l|}{ Behavioral } \\
\hline Past experience & $39.2 \%$ & $40.0 \%$ \\
\hline Expenditure & $34.2 \%$ & $42.2 \%$ \\
\hline Length of stay & $31.7 \%$ & $43.3 \%$ \\
\hline Frequency & $25.0 \%$ & $25.6 \%$ \\
\hline Information sources & $21.7 \%$ & $27.8 \%$ \\
\hline Repurchase intentions & $20.8 \%$ & $27.8 \%$ \\
\hline Tourism activities & $14.2 \%$ & $17.8 \%$ \\
\hline Accommodation* & $10.8 \%$ & $24.4 \%$ \\
\hline Transport mode & $8.3 \%$ & $8.9 \%$ \\
\hline
\end{tabular}

(continued)
Table 2 (Continued)

\begin{tabular}{lrr}
\hline & Initial & Current \\
\hline Sample size & & \\
$\quad<200$ & $11.7 \%$ & $14.4 \%$ \\
$200-399$ & $27.5 \%$ & $35.6 \%$ \\
$400-599$ & $25.8 \%$ & $18.9 \%$ \\
$600-799$ & $5.8 \%$ & $10.0 \%$ \\
$800-999$ & $8.3 \%$ & $3.3 \%$ \\
$1000+$ & $16.7 \%$ & $17.8 \%$ \\
Data analysis method & & \\
Descriptive statistics & $94.2 \%$ & $96.7 \%$ \\
Chi-square & $23.3 \%$ & $33.3 \%$ \\
$t$ Test & $25.0 \%$ & $32.2 \%$ \\
Analysis of variance* & $31.7 \%$ & $45.6 \%$ \\
Factor analysis* & $38.3 \%$ & $56.7 \%$ \\
Cluster analysis* & $11.7 \%$ & $27.8 \%$ \\
Regression & $20.8 \%$ & $24.4 \%$ \\
Correlation analysis & $7.5 \%$ & $6.7 \%$ \\
Discriminant analysis & $5.0 \%$ & $6.7 \%$ \\
Qualitative analysis & $5.0 \%$ & $5.6 \%$ \\
Post hoc** & $4.2 \%$ & $25.6 \%$ \\
Other & $8.3 \%$ & $16.7 \%$ \\
\hline
\end{tabular}

Note. The data analysis methods will be greater than $100 \%$ in some instances due to a combined approach employed by event segmentation researchers. ${ }^{*} p<0.05,{ }^{* *} p<0.001$.

The variables employed by event researchers exhibited similarities over time (see Table 2). The demographic variables age (92.2\%), gender $(91.1 \%)$, education (62.2\%), and income (57.8\%) and the geographic item origin $(64.4 \%)$ in this review were once again the most frequently employed variables. Similarly, the three most applied behavioral items of length of stay (43.3\%), expenditure (42.2\%), past experience $(40.0 \%)$, and the psychographic base of motivations $(53.3 \%)$ were frequently used. Only three of the 24 items produced significantly different findings between the two reviews, with gender $(p=0.000)$, employment $(p=0.026)$, and accommodation $(p=0.009)$ more frequently employed in 2017 when compared to 2010 .

Interestingly, when an online survey method was chosen, approximately a third (36.0\%) of studies chose all four bases, with geographic segmentation not considered in these instances (e.g., King, Chan, \& Funk, 2015; Lamont \& Jenkins, 2013). It should be noted that M. Kruger and Saayman (2015b; $2017)$ employed language $(p=0.00)$ and number of people paid for $(p=0.00)$ consistently (over a dozen times) in this review, variables that were not frequently employed by other researchers in this or the earlier review. This focus on language could 
largely be due to the uniqueness of the dual language of Afrikaans and English exhibited by South African event attendees in their usual lifestyle. Conversely, the focus on the number of people paid for has been a variable focused upon by M. Kruger and Saayman, but not other event attendee segmentation researchers, which rather tend to focus on economic models (Herrero, Sanz, \& Devesa, 2011; Warnick, Bojanic, \& Cariter, 2017) as a basis for profiling attendees.

The usage of past literature in the formation of the event attendee segmentation research instrument produced significant differences $(p=0.00)$ between the two reviews. The current review employed past literature $(72.2 \%)$ as the basis for research much more frequently than studies conducted prior to $2010(64.8 \%)$. Within the initial review it was also noted that secondary data (e.g., K. Kim, Sun, Jogaratham, \& Oh, 2007; LeBlanc, 2003 ) or event industry practitioner-focused studies (e.g., Slack, Rowley, \& Coles, 2008; Taks, Chalip, Green, Kesenne, \& Martyn, 2009), which were used by fewer than three times each in the current review. However, the focus on festival motivational literature (e.g., Formica \& Uysal, 1996; Scott, 1996) was statistically insignificant between both reviews $(p=0.052)$. The current $(65.5 \%)$ and initial (61.8\%) emphasizing motivation across all event types as a relevant segmentation item across different contexts.

Descriptive statistics such as frequencies and means were the most popular method $[96.7 \%$ (current), 94.2\% (initial), $p=0.400$ ] for both reviews. However, unlike Tkaczynski and Rundle-Thiele's (2011) earlier research that identified a high number of studies (15.8\%) employing descriptive statistics as the sole analysis method, only one study in the current review (Mackellar, 2014) exhibited this trait. Potentially due to the usage of data analysis techniques in PASW, the number of segmentation studies employing factor analysis [56.7\% (current), 38.3\% (initial), $p=0.008$ ], analysis of variance [45.6\% (current), 31.7\% (initial), $p=0.040$ ], and cluster analysis $[27.8 \%$ (current), $11.7 \%$ (initial), $p=0.004$ ] have risen in the past 7 years. These three data analysis methods were all employed in the same study to derive segment profiles on twelve occasions (e.g., Alexander, Kim, \& Kim, 2015; Báez \& Devesa, 2014).
A $t$ test was used to compare sample sizes between the two reviews. Although the sample size $(n=888.08)$ is larger for the current review than the initial review $(n=683.90)$, it was not statistically significant $(p=0.340)$. Chi-square tests (see Table 2) indicated that the number or types of bases applied and second, the same size employed, was statistically insignificant. Taken together, these tests indicate that no changes in segmentation practice are evident in the past 5 to 7 years, which is surprising given the growth in big data.

Analysis of variance (ANOVA) was employed to first identify if there was a significant relationship between year of publication and sample size and second whether sample sizes varied according to the data analysis technique used by event segmentation researchers. No significant relationship was found $(p=0.620)$ between year of publication and sample size, indicating that sample size has not increased in more recent years despite the facilitation of data collection techniques (e.g., online methods). Conversely, as outlined in Table 3, significant differences were found between both cluster analysis $(p=0.010)$ and regression $(p=0.000)$ and sample size. It was concluded that of the 25 segmentation studies in the current review that employed cluster analysis, four (Alexander et al., 2015; Getz et al., 2015; K. Kim \& Tucker, 2016; M. Kruger \& Saayman, 2015b) employed sample sizes in excess of 3,000, whereas eight (e.g., C. Lee \& Won, 2012; J. Lee \& Kyle, 2014; Yeh, Hua, \& Huang, 2016) had sample sizes smaller than 500. Similarly, five (e.g., Brida, Disegna, \& Osti, 2013; Lim \& Bendle, 2012; Pechlaner, Dal Bo, \& Pichler, 2013) regression studies had a large sample size $(n>1,000)$ whereas seven studies (e.g., Croes \& Lee, 2015; Savinoic, Kim, \& Long, 2012; Tzetzis, Alexandris, \& Kapsampeli, 2014) had a small sample size $(n<250)$.

When combining all 210 studies from the two reviews, it was again concluded that no significant relationship was found $(p=0.922)$ between year of publication and sample size when multivariate cluster techniques were applied, suggesting there has been no change in sample sizes obtained despite guidelines for market segmentation samples increasing over time (Dolnicar et al., 2014). Furthermore, significance differences were only found between cluster analysis $(p=0.002)$ and regression $(p=0.001)$. 
Table 3

Sample Sizes

\begin{tabular}{lccc}
\hline Data Analysis Technique & $\begin{array}{c}\text { Average Sample Size } \\
\text { Analyzed (Pre-2010) }\end{array}$ & $\begin{array}{c}\text { Average Sample Size } \\
\text { Analyzed (Post-2010) }\end{array}$ & $\begin{array}{c}\text { Average Sample } \\
\text { Size Analyzed (All) }\end{array}$ \\
\hline Descriptive statistics & 682.6 & 886.3 & 772.1 \\
Chi-square & 652.6 & 119.5 & 940.4 \\
$t$ Test & $492.1^{*}$ & 388.6 & 490.3 \\
Analysis of variance & $460.6^{*}$ & 1064.0 & 799.5 \\
Factor analysis & $444.4^{*}$ & 1287.7 & 841.6 \\
Cluster analysis & 808.8 & $1708.5^{*}$ & $1357.4^{*}$ \\
Regression & 806.4 & $4548.5^{*}$ & $1530.7^{*}$ \\
Correlation analysis & 439.0 & 1067.8 & 690.5 \\
Discriminant analysis & 400.4 & 98.8 & 249.6 \\
Qualitative analysis & 617.5 & 622.4 & 621.6 \\
Post hoc & 474.2 & 678.9 & 642.4 \\
Other & 548.9 & 941.5 & 775.4 \\
\hline
\end{tabular}

$* p<0.05$.

Discussion

Event market segmentation continues to remain a dominant area of research enquiry across cultural (e.g., festivals), sports (e.g., World Cups), and business (e.g., conferences) events. Utilizing Tkaczynski and Rundle-Thiele's (2011) previous framework as the basis for a comparison between the initial and current review, the answers to the nine research issues that were asked in the introduction are now discussed in turn.

\section{In Which Journals Are Event Attendee Segmentation Articles Published?}

Event attendee segmentation research continues to be largely published in Event Management. Despite this journal's dominance, a relatively new journal, International Journal of Event and Festival Management, and the established tourism marketing journal, Journal of Travel \& Tourism Marketing, are now providing additional avenues for event attendee segmentation research. Consequently, researchers should consider viewing not only Event Management, but a view variety of available journals when seeking to further develop theory and understand current research practices in event segmentation.

\section{Where Is Event Attendee Segmentation Carried Out?}

The US is the most popular country for event segmentation research across both research reviews. However, since 2010, numerous segmentation studies have been conducted in South Africa and various locations in Europe (e.g., the UK, Germany). Therefore, this suggests that event attendee segmentation research, while occurring across the globe, remains dominated by the US, which may limit understanding. Although this recent review has provided insight into the profile of event attendees, research into cultural events (e.g., M. Kruger \& Saayman, 2015b; M. Kruger et al., 2011) are limited to one country (South Africa). Cross-country comparisons, although present (e.g., Horng et al., 2013; Mair, 2010), are minimal and do not focus on examining cultural differences that may be limiting understanding about whether it is appropriate to derive segments across countries. Although selected studies examine attendee ethnicity (e.g., Báez \& Devesa, 2014; Ko, Kim, Kim, Lee, \& Cattani, 2010) and language differences (e.g., M. Kruger, Myburgh, \& Saayman, 2016; M. Kruger \& Saayman, 2013), further research into segmenting event attendees to extend understanding of inclusion of the impact of cultural factors in segmentation research is recommended (Getz \& Page, 2016).

Which Types of Events Are Researched by Event Attendee Segmentation Researchers?

Cultural events have dominated event attendee research since the 1990s. For example, research at music festivals led both the initial (e.g., Bowen \& 
Daniels, 2005; Formica \& Uysal, 1998) and current (e.g., Blesic, Pivac, Stamenkovic, \& Besermenji, 2013; Oakes, 2010) reviews. Likewise, culinary festivals were a popular context for event attendee segmentation across both reviews (Getz et al., 2015; K.-S. Park, Reisinger, \& Kang, 2008). The diversity of sports is also prevalent in event attendee segmentation research, with running (Agrusa, Lema, Kim, \& Botto, 2009; Aicher, Karadakis, \& Eddosary, 2015) and mega-sport events (Peters \& Schnitzer, 2015; Qi, Gibson, \& Zhang, 2009) prevalent since the initial review. Although special events such as wedding expositions (e.g., Daniels et al., 2012; S. Kruger et al., 2014) represent a relatively new form of events, event attendee segmentation into this field is relatively sparse, which provides opportunities for future research.

\section{What Data Collection Method(s) Have Been Used to Collect Information From Attendees?}

Online surveys are beneficial, permitting data to be gathered in sports events (King et al., 2015; Lamont \& Jenkins, 2013) or for those who travel to locations not usually open to the public such as airbases (Bojanic \& Warnick, 2012; Warnick, Bojanic, Mathur, \& Ninan, 2011). It is interesting to observe that researchers continue to employ selfadministered on-site surveys as the predominant method of data collection. On-site administration, which may be more expensive (Jennings, 2010), may assist to increase representativeness, generalizability, and limit skewness towards one particular cohort (e.g., females) and should be used as a basis for continual event attendee segmentation, despite its time and financial constraints.

\section{Which of the Four Segmentation Bases Developed by Kotler (1980) Are Used by Researchers to Profile Attendees?}

Few changes in the number or types of bases applied and the measures applied over time were noted in this study. A lack of innovation in measures and/or bases may be limiting understanding of the most effective and efficient means to segment and target event attendees. For example, in a tourist context, situation was proposed (Tkaczynski, Rundle-Thiele, \& Prebensen, 2015) as a potential base, which may be applied to extend destination visitation in low tourist seasons.

The geographic base is the least frequently used base in segmentation research. Inclusion of a geographic item in an on-site survey (e.g., S.-B. Kim, Ao, Lee, \& Pan, 2012; Tkaczynski \& Rundle-Thiele, 2013) may provide greater insight into where event attendees usually reside, which can inform event marketing planning. Specifically, inclusion of geographic measures offers diagnostic information to inform targeting and communication efforts (Moscardo, Pearce, \& Morrison, 2001). Economic impact measurement techniques incorporating various data collection methods are being produced (e.g., Warnick et al., 2017). Future research in event segmentation can calculate impact by segments identified to compare and contrast the contributions each segment delivers. This understanding informs resource allocation, ensuring that data drives decision making and that monies are invested to maximize return for the destination thereby benefitting local communities who depend on flow-on effects delivered by events.

\section{What Variables Were Utilized by Researchers to Classify Attendees?}

Multiple bases (and variables) to segmentation have been and should continue to be applied by researchers when profiling attendees. The combination of at least three of Kotler's (1980) segmentation bases have been regularly employed by event segmentation researchers across three decades of research. Furthermore, within this review, gender and age were again identified as the most dominant event segmentation items used in event segmentation research (Tkaczynski \& Rundle-Thiele, 2011). Despite their popularity, their usage as segmentation variables must be used cautiously given research that has found that both age and gender are insignificant variables in differentiating segments (Hallman \& Wicker, 2012; M. Kruger et al., 2016). Therefore, although not the most frequently applied segmentation variable in both reviews, festival motivation has and should continue to be a relevant focus on event attendee research. Armed with this knowledge, event attendee segmentation researchers can identify whether motivational factors such as socialization and enjoyment identified as relevant 
in seminal research across different contexts (e.g., Formica \& Uysal, 1996; Scott, 1996) continue to be relevant in current event attendee research.

Event researchers may find it of greater strategic value to focus on behavioral (e.g., expenditure) and psychographic (e.g., motivations) variables to distinguish segments and descriptive variables (e.g., demographic) to profile tourists (Tkaczynski \& Rundle-Thiele, 2011). Further, although the accommodation option represents a moderately popular behavioral segmentation item (behind more frequently employed variables such as length of stay and expenditure), its industry relevance cannot be understated. Although event segmentation studies have focused extensively on tourists (Pechlaner et al., 2013; Peter \& Anandkumar, 2016), event academics and practitioners may need to conduct future research with new innovative, accommodation options such as AirBnB and Flipkey potentially revolutionizing understanding of how and where event attendees stay during a performance and how this impacts a destination economically. Finally, although information sources such as digital media options (e.g., social media) have increased in prevalence (Liu et al., 2017; Wang \& Cole, 2016), their importance as a segmentation variable remains inconclusive. Future research could examine how event attendees can be differentiated based on how they search for and share information (both online and offline) on their event experience before, during, and after its duration.

\section{What Data Analysis Methods Were Applied to Segment Attendees?}

Descriptive or univariate statistics remain the dominant analysis method for segmentation research. Extending beyond univariate treatment, numerous event segmentation researchers are using bivariate techniques such as analysis of variance (e.g., Daniels et al., 2012; Peter \& Anandkumar, 2014) or regression (e.g., Savinovic et al., 2012; Son $\&$ Lee, 2011) in combination with descriptive statistics to profile attendees. Additionally, data reduction techniques such as factor analysis have been applied to assist researchers to profile segments and reduce data prior to clustering. This article calls for application of multivariate forms of data analysis such as cluster analysis in segmentation research, permitting an event attendee rather than researcher driven profile to emerge.

Multivariate techniques allow researchers to simultaneously consider the role each individual factor has, which is more reflective of reality given identification of an event attendee persona to describe the identified segment involves more than a single variable. With the advancement of technology in data analysis techniques now available in PASW that was largely not available in the 1990s, which represented a major component of the initial review, employing these packages can allow greater analysis and validation (both internal and external), which can inform event attendee segmentation practice.

\section{Have Sample Sizes Increased Over Time and do Sample Sizes Vary According to the Data Analysis Techniques Employed?}

This review identified that samples employed in segmentation studies have not changed significantly in size over time. Although advancements in the amount of data and data collection technology are available to event researchers, it appears access to data may be problematic for researchers, limiting event researchers' ability to reach recommended sample sizes (e.g., Dolnicar \& Grün, 2008; Dolnicar et al., 2014). This problem could be explained by the potentially small population (e.g., $<500$ people) at minor events such as specialized cultural celebrations or focused sports carnivals.

Limitations and Opportunities for Future Research

This research is not without its limitations. This review is based on a previous synthesis framework and is, therefore, restricted to the agenda reported in the earlier 2010 study. Consequently, certain analysis techniques such as the external validation employed by multivariate analysis cannot be compared and contrasted due to the unavailability of many data analysis multivariate techniques and their associated validated techniques (e.g., Two-Step Cluster Analysis) in the initial review (Tkaczynski \& Rundle-Thiele, 2011). Secondly, this study has determined how event attendees are profiled but it has not aimed to identify why selected processes were employed. Future research can examine whether common sense or data-driven segmentation 
(Dolnicar, 2004) approaches were considered by researchers and if theory development or theory testing was the aim for the research.

Future research opportunities for event segmentation research could include examining segmentation studies across different continents and across different event types to identify whether salient/ important profiling attributes exist given the event context or country studied. Although festival motivation research based on previous literature has and will likely dominate event attendee segmentation research, an opportunity for future segmentation research is to segment a cohort of event attendees at different time periods (potentially before and after an event) to identify whether segments can be validated over time such as whether their motivations were fulfilled. Studying the validity measures employed by academics to profile attendees into specific segments (e.g., clusters) through multivariate analysis presents an opportunity for future research, considering the noted advancements in quantitative analysis in event research.

Finally, a research area of concern noted by Getz and Page (2016) is the lack of longitudinal event research. Additionally, longitudinal data assessments permit researchers to examine the predictive capability of segments derived. By understand the extent (or not) that a segment solution can explain event attendance behavior researchers can compare and contrast bases and measures used. Comparisons and contrasts permit identification of optimal measures and bases for prediction. Research effort that is directed towards assessing predictive capability of alternatives enhances the precision of our decision support tools over time.

\section{References}

Agrusa, J. F., Lema, J. D., Kim, S. S., \& Botto, D. (2009). The impact of consumer behavior and service perceptions of a major sport tourism event. Asia Pacific Journal of Tourism Research, 14(3), 267-277.

Aicher, T. J., Karadakis, K., \& Eddosary, M. M. (2015). Comparison of sport tourists' and locals' motivation to participate in a running event. International Journal of Event and Festival Management, 6(3), 215-234. doi: https://doi.org/10.1108/IJEFM-03-2015-0011

Akyeampong, O. A., \& Yankholmes, A. (2016). Profiling masquerade festival attendees in Ghana. Event Management, 20(2), 285-296. doi: https://doi.org/10.3727/1525 99516X14643674421933
Alexander, A., Kim, S.-B., \& Kim, D.-Y. (2015). Segmenting volunteers by motivation in the 2012 London Olympic Games. Tourism Management, 47, 1-10. doi: https:// doi.org/10.1016/j.tourman.2014.09.002

Allen, J., O’Toole, W., Harris, R., \& McDonnell, I. (2008). Festival and special event management. Milton, Australia: John Wiley \& Sons.

Báez, A., \& Devesa, M. (2014). Segmenting and profiling attendees of a film festival. International Journal of Event and Festival Management, 5(2), 96-115. doi: https://doi.org/10.1108/IJEFM-08-2013-0021

Barquet, A., Gabriel, J., Osti, L., \& Schubert, S. (2011). An analysis of tourists' expenditure on winter sports events through the Tobit Censorate Model. Tourism Economics, 17(6), 1197-1217. doi: https://doi.org/10.5367/te.2011.0084

Bernthal, M., Nagel, M., Harrill, R., \& Riner, P. (2012). All work and no work makes Jack a dull boy: An exploration of business travelers' attendance at live, ticketed entertainment events. Tourism Analysis, 17(2), 213-224. doi: https://doi.org/10.3727/108354212X13388995267940

Blesic, I., Pivac, T., Stamenkovic, I., \& Besermenji, S. (2013). Motives of visits to ethno music festivals with regard to gender and age structure of visitors. Event Management, 17(2), 145-154. doi: https://doi.org/10.37 27/152599513X13668224082387

Bojanic, D. C., \& Warnick, R. B. (2012). The role of purchase decision involvement in a special event. Journal of Travel Research, 51(3), 357-366. doi: https://doi. org $/ 10.1177 / 0047287511418364$

Bosnjak, M., Brown, C. A., Lin, D.-J., Yu, G. B., \& Sirgy, M. J. (2016). Self-expressiveness in sport tourism: Determinants and consequences. Journal of Travel Research, 55(1), 125-134. doi: https://doi. org/10.1177/0047287514535845

Bowen, H. E., \& Daniels, M. J. (2005). Does the music matter? Motivations for attending a music festival. Event Management, 9(3), 155-164.

Brida, J. G., Disegna, M., \& Osti, L. (2013). The effect of authenticity on visitors' expenditure at cultural events. Current Issues in Tourism, 16(3), 266-285. doi: https:// doi.org/10.1080/13683500.2012.674105

Byrd, E. T., Beedle, J., \& Cardenas, D. A. (2014). Repeat visitation and visitor spending at events: Hogs and muscle cars. Event Management, 18(2), 101-110. doi: https:// doi.org/10.3727/152599514X13947236947301

Carlsen, J., Rosenberger III, P. J., \& Rahman, M. M. (2016). A hierarchical model of perceived value of group-oriented travel experiences to major events and its influences on satisfaction and future group-travel intentions. Journal of Travel \& Tourism Marketing, 33(9), 1251-1267. doi: https://doi.org/10.1080/10548408.2015.1117407

Case, R., Dey, T., Hobbs, S., Hoolachan, J., \& Wilcox, A. (2010). An examination of sporting event directspending patterns at three competitive levels. Journal of Convention \& Event Tourism, 11(2), 1191-1137. doi: https://doi.org/10.1080/15470148.2010.485178

Cetin, G., \& Bilgihan, A. (2016). Components of cultural tourists' experiences in destinations. Current Issues in 
Tourism, 19(2), 137-154. doi: https://doi.org/10.1080/ 13683500.2014 .994595

Chang, W., \& Yuan, J. (2011). A taste of tourism: Visitors' motivations to attend a food festival. Event Management, 15(1), 13-23.

Chiang, L., Xu, A., Kim, J., Tang, L., \& Manthiou, A. (2017). Investigating festivals and events as social gatherings: The application of social identity theory. Journal of Travel \& Tourism Marketing, 34(6), 779-792. doi: https://doi.org/10.1080/10548408.2016.1233927

Croes, R., \& Lee, S. H. (2015). Women at a music festival: Biological sex defining motivation and behavioral intentions. Event Management, 19(2), 275-289. doi: https:// doi.org/10.3727/152599515X14297053839818

Daniels, M. J., Lee, S. H., \& Cohen, T. (2012). The attributes influencing wedding reception venue selection. Event Management, 16(3), 245-258. doi: https://doi.org/10.37 27/152599512X13459279626845

Dolnicar, S. (2004). Beyond "commonsense segmentation": A systematics of segmentation approaches in tourism. Journal of Travel Research, 42(3), 244-250. doi: https:// doi.org/10.1177/0047287503258830

Dolnicar, S., \& Grün, B. (2008). Challenging “factor-cluster segmentation." Journal of Travel Research, 47(1), 63-71. doi: https://doi.org/10.1177/0047287508318910

Dolnicar, S., Grün, B., \& Leisch, F. (2014). Required sample sizes for data-driven market segmentation analyses in tourism. Journal of Travel Research, 53(4), 296-306. doi: https://doi.org/10.1177/0047287513496475

Dolnicar, S., Grün, B., \& Leisch, F. (2016). Increasing sample size compensates for data problems in segmentation studies. Journal of Business Research, 69(2), 992-999. doi: https://doi.org/10.1016/j.jbusres.2015.09.004

Filo, K., Chen, N., King, C., \& Funk, D. C. (2013). Sport tourists' involvement with a destination: A stage-based examination. Journal of Hospitality \& Tourism Research, 37(1), 100-124. doi: https://doi. org/10.1177/1096348011425496

Fonseca, J. R. S., \& Ramos, R. M. P. (2014). Segmenting and profiling the Portuguese festival-goers through the most ancient form of music retailing: The music festivals. Journal of Convention \& Event Tourism, 15(4), 271-297. doi: https://doi.org/10.1080/15470148.2014.9 61668

Formica, S., \& Uysal, M. (1996). A market segmentation of festival visitors: Umbria Jazz festival in Italy. Festival Management \& Event Tourism, 3(4), 175-182.

Formica, S., \& Uysal, M. (1998). Market segmentation on an international cultural-historical event in Italy. Journal of Travel Research, 36(4), 16-24. doi: https://doi. org/10.1177/004728759803600402

Gallarza, M. G., Artegaga, F., \& Gil-Saura, I. (2013). The value of volunteering in special events: A longitudinal study. Annals of Tourism Research, 40(January), 105131. doi: https://doi.org/10.1016/j.annals.2012.08.001

Getz, D. (2007). Event studies: Theory, research and policy for planned events. Oxford, UK: ButterworthHeinemann.
Getz, D. (2008). Event tourism: Definition, evolution and research. Tourism Management, 29(3), 403-428. doi: https://doi.org/10.1016/j.tourman.2007.07.017

Getz, D., Andersson, T., Vujicic, S., \& Robinson, R. N. S. (2015). Food events in lifestyle and travel. Event Management, 19(3), 407-419. doi: https://doi.org/10.3727/1 $52599515 X 14386220874968$

Getz, D., \& McConnell, A. (2014). Comparing trail runners and mountain bikers: Motivation, involvement, portfolios, and event tourist careers. Journal of Convention \& Event Tourism, 15(1), 69-100. doi: https://doi.org/10.10 80/15470148.2013.834807

Getz, D., \& Page, S. J. (2016). Progress and prospects for event tourism research. Tourism Management, 52, 593631. doi: https://doi.org/10.1016/j.tourman.2015.03.007

Hallmann, K., \& Wicker, P. (2012). Consumer profiles of runners at marathon races. International Journal of Event and Festival Management, 3(2), 171-187. doi: https:// doi.org/10.1108/17582951211229717

Herrero, L. S., Sanz, J. A., \& Devesa, M. (2011). Measuring the economic value and social viability of a cultural festival as a tourism prototype. Tourism Economics, 17(3), 639-653. https://doi.org/10.5367/te.2011.0057

Horng, J.-S., Su, C.-S., \& So, S.-I. A. (2013). Segmenting food festival visitors: Applying the theory of planned behavior and lifestyle. Journal of Convention \& Event Tourism, 14(3), 193-216. doi: https://doi.org/10.1080/1 5470148.2013 .814038

Hyde, K. F., \& Harman, S. (2011). Motives for a secular pilgrimage to the Gallipoli battlefields. Tourism Management, 32(6), 1343-1351. doi: https://doi.org/10.1016/j. tourman.2011.01.008

Jennings, G. (2010). Tourism research (2nd ed.). Milton, Australia: John Wiley and Sons.

Kaplanidou, K., \& Gibson, H. (2012). Differences between first time and repeat spectator tourists of a youth soccer event: Intentions and image approaches. Current Issues in Tourism, 15(5), 477-487. doi: https://doi.org/10.1080/ 13683500.2011 .607924

Karvonen, M., \& Komppula, R. (2013). Motivation-based segments of the Sulkava rowing race event visitors. Event Management, 17(4), 409-423. doi: https://doi.org/ $10.3727 / 152599513 X 13769392444701$

Kim, K., Sun, J., Jogaratham, G., \& Oh, I.-K. (2007). Market segmentation by activity preferences: Validation of cultural festival. Event Management, 10(4), 221-229.

Kim, K., \& Tucker, E. D. (2016). Assessing and segmenting entertainment quality variables and satisfaction of live event attendees: A cluster analysis examination. Journal of Convention \& Event Tourism, 17(2), 112-128. doi: https://doi.org/10.1080/15470148.2015.1101035

Kim, S.-B., Ao, Y., Lee, H., \& Pan, S. (2012). A study of motivations and the image of shanghai as perceived by foreign tourists at the Shanghai EXPO. Journal of Convention \& Event Tourism, 13(1), 48-73. doi: https://doi.o $\mathrm{rg} / 10.1080 / 15470148.2012 .651972$

King, C., Chan, N., \& Funk, D. C. (2015). Exploring destination image decay: A study of sport tourists' destination 
image change after event participation. Journal of Hospitality \& Tourism Research, 39(1), 3-31. doi: https://doi. org/10.1177/1096348012461547

Ko, Y. J., Kim, M. K., Kim, Y. K., Lee, J.-H., \& Cattani, K. (2010). Consumer satisfaction and event quality perception: A case of US Open Taekwondo Championship. Event Management, 14(3), 205-214. doi: https://doi.org/ 10.3727/152599510X12825895093597

Kotler, P. (1980). Principles of marketing. Englewood Cliffs, NJ: Prentice-Hall.

Kruger, M., Myburgh, E., \& Saayman, M. (2016). A motivationbased typology of road cyclists in the Cape Town Cycle Tour, South Africa. Journal of Travel \& Tourism Marketing, 33(3), 380-403. doi: https://doi.org/10.1080/10548408.201 5.1064057

Kruger, M., \& Saayman, M. (2012a). Listen to your heart: Motives for attending Roxette Live. Journal of Convention \& Event Tourism, 13(3), 181-202. doi: https://doi.or g/10.1080/15470148.2012.715996

Kruger, M., \& Saayman, M. (2012b). Show me the band and I will show you the market. Journal of Convention \& Event Tourism, 13(4), 250-269. doi: https://doi.org/10.1 080/15470148.2012.728973

Kruger, M., \& Saayman, M. (2012c). When do festinos decide to attend an arts festival? An Analysis of the Innibos National Arts Festival. Journal of Travel \& Tourism Marketing, 29(2), 147-162. doi: https://doi.org/10.1080/ 10548408.2012.648538

Kruger, M., \& Saayman, M. (2013). Assessing the viability of first-time and repeat visitors to an international jazz festival in South Africa. Event Management, 17(3), 179-194. doi: https://doi.org/10.3727/152599513X1366 8224082422

Kruger, M., \& Saayman, M. (2015a). Attendance at the U2 concert: Is it a case of "this is a man's world?" Event Management, 19(1), 15-32. doi: https://doi.org/10.3727/ $152599515 X 14229071392864$

Kruger, M., \& Saayman, M. (2015b). Consumer preferences of Generation Y: Evidence from live music tourism event performances in South Africa. Journal of Vacation Marketing, 21(4), 366-382. doi: https://doi. org/10.1177/1356766715585903

Kruger, M., \& Saayman, M. (2016a). A 3E typology of visitors at an electronic dance music festival. International Journal of Event and Festival Management, 7(3), 219-236. doi: https://doi.org/10.1108/IJEFM-042016-0027

Kruger, M., \& Saayman, M. (2016b). Understanding the Zion Christian Church (ZCC) pilgrims. International Journal of Tourism Research, 18(1), 27-38. doi: https:// doi.org/10.1002/jtr.2030

Kruger, M., \& Saayman, M. (2017). Segmenting beyond behavioural intentions: Fine tuning music festival visitors' music appreciation. International Journal of Event and Festival Management, 8(2), 204-223. doi: https:// doi.org/10.1108/IJEFM-09-2016-0064

Kruger, M., Saayman, M., \& Ellis, S. M. (2010). Determinants of visitor expenditure at the Aardklop National
Arts Festival. Event Management, 14(2), 137-148. doi: https://doi.org/10.3727/152599510X12766070300966

Kruger, M., Saayman, M., \& Ellis, S. M. (2011). Segmentation by genres: The case of the Aardklop National Arts Festival. International Journal of Tourism Research, 13(6), 511-526. doi: https://doi.org/10.1002/jtr.818

Kruger, M., Saayman, M., \& Ellis, S. M. (2012). Determinants of visitor spending: An evaluation of participants and spectators at the Two Oceans Marathon. Tourism Economics, 18(6), 1203-1227. doi: https://doi. org $/ 0.5367 /$ te. 2012.0174

Kruger, S., Saayman, M., \& Ellis, S. M. (2014). The influence of travel motives on visitor happiness attending a wedding expo. Journal of Travel \& Tourism Marketing, 31(5), 649-665. doi: https://doi.org/10.1080/10548408. 2014.883955

Lamont, M., \& Jenkins, J. (2013). Segmentation of cycling event participants: A two-step cluster method using recreation specialisation. Event Management, 17(4), 391-407. doi: https://doi.org/10.3727/152599513X13769392444666

LeBlanc, M. (2003). Tourist characteristics and their interest in attending festivals and events: An anglophone/francophone case study of New Brunswick, Canada. Event Management, 8(4), 203-212.

Lee, C., \& Won, D. (2012). Understanding segmented spectator markets of a minor league baseball (MiLB) team. Event Management, 16(4), 351-362. doi: https://doi.org/ $10.3727 / 152599512 X 13539583375171$

Lee, I. S., Lee, T. J., \& Arcodia, C. (2014). The effect of community attachment on cultural festival visitors' satisfaction and future intentions. Current Issues in Tourism, 19(7), 800-812. doi: https://doi.org/10.1080/13683500. 2013.770450

Lee, J., \& Kyle, G. T. (2014). Segmenting festival visitors using psychological commitment. Journal of Travel Research, 53(5), 656-669. doi: https://doi.org/10.1177/ 0047287513513168

Lee, M. J., Yeung, S., \& Dewald, B. (2010). An exploratory study examined the determinants of attendance motivations as perceived by attendees at Hong Kong exhibitions. Journal of Convention \& Event Tourism, 11(3), 195-208. doi: https://doi.org/10.1080/15470148.2010.5 07135

Lee, S., Boshnakova, D., \& Goldblatt, J. (2017). The 21st Century meeting and event technologies: Powerful tools for better planning, marketing and evaluation (1st ed.). Ontario, Canada: Apple Academic Press.

Lim, C. C., \& Bendle, L. J. (2012). Arts tourism in Seoul: Tourist-orientated performing arts as a sustainable niche market. Journal of Sustainable Tourism, 20(5), 667-682. doi: https://doi.org/10.1080/09669582.2011.636817

Liu, Y., Teichert, T., Rossi, M., Li, H., \& Hu, F. (2017). Big data for big insights: Investigating language-specific drivers of hotel satisfaction with 412,784 user-generated reviews. Tourism Management, 59, 554-563. doi: https:// doi.org/10.1016/j.tourman.2016.08.012

Lyu, S. O., \& Lee, H. (2013). Market segmentation of golf event spectators using leisure benefits. Journal of Travel 
\& Tourism Marketing, 30(3), 186-200. doi: https://doi.o $\mathrm{rg} / 10.1080 / 10548408.2013 .774913$

Mackellar, J. (2014). Surfing the fringe: An examination of event tourism strategies of the bleach festival - Coolangatta Queensland. Event Management, 18(4), 447-455. doi: https://doi.org/10.3727/152599514X14143427352193

Mahadevan, R. (2014). Understanding senior self-drive tourism in Australia using a contingency behavior model. Journal of Travel Research, 53(2), 252-259. doi: https:// doi.org/10.1177/0047287513496476

Mair, J. (2010). Profiling conference delegates using attendance motivations. Journal of Convention \& Event Tourism, 11(3), 176-194. doi: https://doi.org/10.1080/154701 48.2010 .502032

Matejevic, M., Wallrabenstein, K., \& Ristic, Z. (2015). Tourist dimension of canine events. Event Management, 19(2), 291-302. doi: https://doi.org/10.3727/152599515 X14297053839854

McDowall, S. (2010). A comparison between Thai residents and non-residents in their motivations, performance evaluations, and overall satisfaction with a domestic festival. Journal of Vacation Marketing, 16(3), 217-233. doi: https://doi.org/10.1177/1356766709356139

Mikulić, J., Paunović, Z., \& Prebežac, D. (2012). An extended neural network-based importance-performance analysis for enhancing wine fair experience. Journal of Travel \& Tourism Marketing, 29(8), 744-759. doi: https://doi.org/10.1080/10548408.2012.730936

Moscardo, G., Pearce, P., \& Morrison, A. (2001). Evaluating different bases for market segmentation: A comparison of geographic origin versus activity participation for generating tourist market segments. Journal of Travel \& Tourism Marketing, 10(1), 29-49. doi: https://doi. org/10.1300/J073v10n01_03

Nicholson, R., \& Pearce, D. (2000). Who goes to events? A comparative analysis of the profile characteristics of visitors to four South Island events in New Zealand. Journal of Vacation Marketing, 6(3), 236-253.

Oakes, S. (2010). Profiling the jazz festival audience. International Journal of Event and Festival Management, 1(2), 110-119. doi: https://doi.org/10.1108/17852951011056892

Okubo, K., Gardebroek, C., \& Heijman, W. (2014). The economic value and roles of rural festivals in Japan. Tourism Economics, 20(5), 1125-1132. doi: https://doi. org/10.5367/te.2013.0344

Pan, B., \& Yang, Y. (2017). Monitoring and forecasting tourism activities with big data. In M. Uysal, Z. Schwartz, \& E. Sirakaya-Turk (Eds.), Management science in hospitality and tourism: Theory, practice, and applications (pp. 44-62). Oakville, Canada: Taylor \& Francis.

Park, E., \& Boo, S. (2010). An assessment of convention tourism's potential contribution to environmentally sustainable growth. Journal of Sustainable Tourism, 18(1), 95-113. doi: https://doi.org/10.1080/09669580903147936

Park, K. (2016). Determinants of spending by motorcycle rally visitors. Event Management, 20(2), 255-265. doi: https://doi.org/10.3727/152599516X14643674421852
Park, K.-S., Reisinger, Y., \& Kang, H.-J. (2008). Visitors' motivation for attending the South Beach Wine and Food Festival, Miami Beach, Florida. Journal of Travel \& Tourism Marketing, 25(2), 161-181.

Pechlaner, H., Dal Bo, G., \& Pichler, S. (2013). Differences in perceived destination image and event satisfaction among cultural visitors: The case of the European Biennial of Contemporary Art "Manifesta 7." Event Management, 17(2), 123-133. doi: https://doi.org/10.3727/1525 99513X13668224082305

Peter, S., \& Anandkumar, V. (2014). Dubai shopping festival: Tourists' nationality and travel motives. International Journal of Event and Festival Management, 5(2), 116-131. doi: https://doi.org/10.1108/IJEFM-08-2013-0022

Peter, S., \& Anandkumar, V. (2016). Travel motivationbased typology of tourists who visit a shopping festival: An empirical study on the Dubai shopping festival. Journal of Vacation Marketing, 22(2), 142-153. doi: https:// doi.org/10.1177/1356766715607587

Peters, M., \& Schnitzer, M. (2015). Athletes' expectations, experiences, and legacies of the Winter Youth Olympic Games Innsbruck 2012. International Journal of Event and Festival Management, 16(2), 116-144. doi: https:// doi.org/10.1080/15470148.2015.1018656

Pilcher, D. R., \& Eade, N. (2016). Understanding the audience: Purbeck Folk Festival. International Journal of Event and Festival Management, 7(1), 21-49. doi: https://doi.org/10.1108/IJEFM-09-2015-0039

Poisson, D. K., \& Chen, R. J. C. (2010). Multiple on-site winery festivals: Tourist motivations, winery festival destination performance, and repatronage intention. Tourism Analysis, 15(5), 585-589. doi: https://doi.org/10 $.3727 / 108354210 X 12889831783431$

Preston, C. A. (2012). Event marketing: How to successfully promote events, festivals, conventions, and expositions (2nd ed.). Hoboken, NJ: John Wiley \& Sons.

Qi, C. X., Gibson, H. J., \& Zhang, J. J. (2009). Perceptions of risk and travel intentions: The case of China and the Beijing Olympic Games. Journal of Sport \& Tourism, 14(1), 43-67.

Rittichainuwat, B., \& Mair, J. (2012). Visitor attendance motivations at consumer travel exhibitions. Tourism Management, 33(5), 1236-1244. doi: https://doi.org/10.1016/j. tourman.2011.11.002

Rivera, M. A., Semrad, K. J., \& Croes, R. (2016). The internationalization benefits of a music festival: The case of the Curacao North Sea Jazz Festival. Tourism Economics, 22(5), 1087-1103. doi: https://doi.org/10.5367/ te. 2015.0485

Robinson, R. N. S., \& Clifford, C. (2012). Authenticity and festival foodservice experiences Annals of Tourism Research, 39(2), 571-600. doi: https://doi.org/10.1016/j. annals.2011.06.007

Saayman, M., \& Saayman, A. (2012). The economic impact of the Comrades Marathon. International Journal of Event and Festival Management, 3(3), 220-235. doi: https://doi.org/10.1108/17582951211262675 
Saayman, M., Saayman, A., \& Joubert, E.-M. (2012). Expenditure-based segmentation of visitors to the Wacky Wine Festival. Tourism Recreation Research, 37(3), 215-225. doi: https://doi.org/10.1080/02508281. 2012.11081710

Savinovic, A., Kim, S.-B., \& Long, P. (2012). Audience members' motivation, satisfaction, and intention to revisit an ethnic minority cultural festival. Journal of Travel \& Tourism Marketing, 29(7), 682-694. doi: https://doi.o $\mathrm{rg} / 10.1080 / 10548408.2012 .720154$

Scott, D. (1996). A comparison of visitors' motivations to attend three urban festivals. Festival Management \& Event Tourism, 3(3), 121-128.

Shen, S. (2014). Intention to revisit traditional folk events: A case study of Qinhuai Lantern Festival, China. International Journal of Tourism Research, 16(5), 513-520. doi: https://doi.org/10.1002/jtr.1949

Slack, F., Rowley, J., \& Coles, S. (2008). Consumer behaviour in multi-channel contexts: The case of a theatre festival. Internet Research, 18(1), 46-59.

Son, S. M., \& Lee, K. M. (2011). Assessing the influences of festival quality and satisfaction on visitor behavioural intentions. Event Management, 15(3), 293-303. doi: https://doi.org/10.3727/152599511X13124625650700

Szmigin, I., Bengry-Howell, A., Morey, Y., Griffin, C., \& Riley, S. (2017). Socio-spatial authenticity at co-created music festivals. Annals of Tourism Research, 63, 1-11. doi: https://doi.org/10.1016/j.annals.2016.12.007

Taks, M., Chalip, L., Green, B. C., Kesenne, S., \& Martyn, N. (2009). Factors affecting repeat visitation and flow-on tourism as sources of event strategy sustainability. Journal of Sport \& Tourism, 14(2), 121-142.

Tanford, S., Montgomery, R., \& Nelson, K. B. (2012a). Factors that influence attendance, satisfaction, and loyalty for conventions. Journal of Convention \& Event Tourism, 13(4), 290-318. doi: https://doi.org/10.1080/15470 148.2012.728975

Tanford, S., Montgomery, R., \& Hetzman, J. (2012b). Towards a model of wine event loyalty. Journal of Convention \& Event Tourism, 13(2), 77-99. doi: https://doi.o $\mathrm{rg} / 10.1080 / 15470148.2012 .673246$

Tkaczynski, A. (2013). Flower power? Activity preferences of residents and tourists to an Australian flower festival. Tourism Analysis, 18(5), 607-613. doi: https://doi.org/10 $.3727 / 108354213$ X13782245307993

Tkaczynski, A., \& Rundle-Thiele, S. R. (2011). Event segmentation: A review and research agenda. Tourism
Management, 32(2), 426-434. doi: https://doi.org/10.1016/ j.tourman.2010.03.010

Tkaczynski, A., \& Rundle-Thiele, S. R. (2013). Understanding what really motivates attendance: A music festival segmentation study. Journal of Travel \& Tourism Marketing, 30(6), 610-623. doi: https://doi.org/10.1080/105 48408.2013.810998

Tkaczynski, A., Rundle-Thiele, S. R., \& Prebensen, N. K. (2015). Segmenting potential nature-based tourists based on temporal factors: The case of Norway. Journal of Travel Research, 54(2), 251-265. doi: https://doi. org/10.1177/0047287513514296

Tzetzis, G., Alexandris, K., \& Kapsampeli, S. (2014). Predicting visitors' satisfaction and behavioral intentions from service quality in the context of a small-scale outdoor sport event. International Journal of Event and Festival Management, 5(1), 4-21. doi: https://doi. org/10.1108/IJEFM-04-2013-0006

Wang, W., \& Cole, S. T. (2016). A comparative analysis of event attendees' spending behaviours, satisfaction, and information search patterns by event types at a midwestern college town. Event Management, 20(1), 3-10. doi: https://doi.org/10.3727/152599516X14538 326024874

Warnick, R. B., Bojanic, D. C., \& Cariter, E. (2017). A comparison of economic impact measurement techniques for a tourism special event. Journal of Travel Research, 56(5), 578-592. doi: https://doi.org/10.1177/0047287516643412

Warnick, R. B., Bojanic, D. C., Mathur, A., \& Ninan, D. (2011). Segmenting event attendees based on travel distance, frequency of attendance, and involvement measures: A cluster segmentation technique. Event Management, 15(1), 77-90. doi: https://doi.org/10.3727/152 599511X12990855575222

Wicker, P., \& Hallmann, K. (2013). Estimating consumer's willingness-to-pay for participation in and travelling to marathon events. Event Management, 17(3), 271-282. doi: https://doi.org/10.3727/152599513X13708863377953

Yeh, C.-C., Hua, K.-T., \& Huang, C.-H. (2016). Service quality improving effects and recreational benefits for sports tourist-A case study. Tourism Economics, 22(6), 13321337. doi: https://doi.org/10.1177/1354816616672357

Yolal, M., Rus, R. V., Cosma, S., \& Gursoy, D. (2015). A pilot study on spectators' motivations and their socioeconomic perceptions of a film festival. Journal of Convention \& Event Tourism, 16(3), 253-271. doi: https:// doi.org/10.1080/15470148.2015.1043610 
